\title{
Alteration in the distribution of Type IV collagen in glomerular basal laminae in diabetic rats as revealed by immunocytochemistry and morphometrical approach
}

\author{
M. Bendayan \\ Department of Anatomy, Faculty of Medicine, University of Montreal, Montreal, Quebec, Canada
}

\begin{abstract}
Summary. The gomerular basal laminae of normoglycaemic and long-term streptozotocin-induced hyperglycaemic rats was studied by morphometrical and immunocytochemical approaches. Using the orthogonal intercept method, we have confirmed that in long-term diabetes, the thickness of the glomerular basal laminae increases significantly. Applying the high resolution protein A-gold immunocytochemical technique, type IV collagen was localized in the glomerular basal laminae. In tissues from normoglycaemic animals the labell-
\end{abstract}

ing was present over the central lamina densa. However, the labelling obtained over the thickened glomerular basal laminae of the hyperglycaemic animals was restricted to the subendothelial site of the lamina. Thus major alteration in the distribution of type IV collagen occurs during the development of diabetic microangiopathy in hyperglycaemic animals.

Key words: Diabetes, microangiopathy, glomerular basal laminae, Type IV collagen, immunocytochemistry, protein A-gold.
Morphological, biochemical and functional alterations have been described in blood capillaries of various organs and tissues of diabetic subjects. These alterations constitute the characteristic features of diabetic microangiopathy [1]. While the morphological thickening of basal laminae has been well documented in various tissues [2-6], the biochemical and functional alterations, which concern the composition of basal lamina material and the loss of the filtration selectivity, accompanied by an increase in capillary permeability, have been well described only for the glomerulus and for a preparation of isolated capillaries [7-12]. However, a controversy has been raised concerning the biochemical changes occurring in the diabetic glomerular basal laminae [13].

Recently, through biochemical and immunochemical approaches, several components of the basal laminae have been isolated and characterized $[14,15]$. These comprise type IV collagen, three non-collagenous glycoproteins, laminin, entactin and fibronectin as well as a heparan sulphate proteoglycan. Application of various immunocytochemical techniques has allowed for the localization of these different components in basal laminae of tissues from normal animals [16-19]. Although the distribution and three dimensional arrangement of basal lamina components may constitute the basis for the selectivity of capillary permeability [20,21], they have been little investigated in tissues from diabetic animals. Recently however, some studies have detect- ed biochemical alterations in the proteoglycan component of 'diabetic' basal laminae [22-24]. Consequently, we are studying the ultrastructural localization of the different components of the basal lamina in renal tissues from normal and streptozotocin-diabetic rats by applying the high resolution protein A-gold immunocytochemical technique $[25,26]$. Our first step, which is reported in the present study, was to localize type IV collagen.

\section{Materials and methods}

An experimental hyperglycaemic state was induced in 100-g SpragueDawley albino male rats by i. v. injection of streptozotocin $(50 \mathrm{mg} / \mathrm{kg}$ body weight, disolved in $10 \mathrm{mmol} / \mathrm{I}$ sodium citrate, $\mathrm{pH}$ 4.5) [27]. Eight animals maintained hyperglycaemic for $7-15$ months were studied. Six animals injected with the same volume of sodium citrate were used as controls. None of the animals were insulin treated. Urine samples were collected and analysed weekly for the presence of glucose and ketone bodies as well as for $\mathrm{pH}$ (reagent strip N-Multiplex, Ames, Ontario, Canada). The animals studied exhibited glycosuria $24 \mathrm{~h}$ after the streptozotocin injection and urinary glucose remained positive throughout the experiment. These animals also showed strong ketonuria with the urine $\mathrm{pH} \sim 5$. At the time of sacrifice, body weight for the streptozotocininjected rats averaged $300 \mathrm{~g}$ versus $700 \mathrm{~g}$ for the control animals. Blood samples were taken at the moment of sacrifice and analyzed for plasma glucose and insulin levels. The enzymatic glucoseoxidase method using glucose analyzer (ERA-2001, Beckman Instruments, Palo Alto, USA) and radioimmunoassay (insulin RIA Kit, Chromacod, BIORIA, Montreal, Canada) were employed [28, 29]. 
The pancreatic tissue of the different animals was fixed by immersion in Bouin's fluid and embedded in paraffin. Sections $(5 \mu \mathrm{m})$ were strained by the indirect immunofluorescent technique [30] using an anti-insulin antibody (Miles Laboratory, Elkhart, Ind., USA) to locate insulin secreting cells.

For the study of renal tissue at the electron microscope level, small fragments of the renal cortex were fixed by immersion in $0.1 \mathrm{~mol} / 1$ phosphate buffer freshly prepared $4 \%$ formaldehyde $(\mathrm{pH} 7.4)$ for $2 \mathrm{~h}$ at $4^{\circ} \mathrm{C}$ and embedded in Lowicryl K4M (Chemische Werke Lowi $\mathrm{GmbH}$ Waldkraiburg, FRG) at $-20^{\circ} \mathrm{C}$ as described previously [25]. These conditions of fixation and embedding were found to be optimal for the ultrastructural localization of type IV collagen by the protein A-gold immunocytochemical technique [31].

A large number of glomerular profiles were examined for each animal using either routine transmission electron microscopy or immunoelectron microscopy after revealing type IV collagen. For measurement of the glomerular basal laminae thickness, micrographs of the glomeruli were recorded at an initial magnification of $\times 5,000$. The thickness of the capillary basal laminae was measured using the orthogonal intercept method [32]. For morphometrical evaluation, each negative was printed at a final magnification of $\times 40,000$. The distance between the endothelial cell and the podocyte was evaluated using a ruler on which the length was classified according to a log-reciprocal scale [32]. A minimum of 200 measurements were made for each sample. Each analysis was performed 'blindly' in random sequence, using a modular system for quantitative digital image analysis (MOP-3, Carl Zeiss Inc. Montreal, Canada).

For the immunocytochemical study of type IV collagen, specific antibodies provided by Dr. G. Martin (National Institute of Health, Bethesda, Maryland, USA) and the protocol for the protein A-gold technique [25] were used. These antibodies were raised in sheep using an antigen extracted from the mouse EHS tumor and purified by salt precipitation and ion exchange chromatography [33,34]; they react with basal laminae of various animal tissues and in particular with rat glomerular basal laminae [16, 18], and their high specificity has been demonstrated previously using several approaches $[16,18,35]$. To locate type IV collagen, the protein A-gold immunocytochemical postembedding approach was applied [25]. In short, the thin sections of renal tissue were first incubated with the specific antibody at 1/10 dilution in phosphate buffer for $2 \mathrm{~h}$ at room temperature and after rinsing, the sections were further incubated for $30 \mathrm{~min}$ with the protein A-gold complex. This complex was prepared using gold particles of $14 \mathrm{~nm}$ diameter [25] and to enhance the contrast for viewing the gold particles at low magnification, the sections were only lightly stained with uranyl acetate. Tissues from normoglycaemic and hyperglycaemic animals were processed in parallel.

The exact location of the gold label at the level of the glomerular basal laminae was further analyzed by morphometry. The distance between each individual gold particle and the cell membrane of the endothelial cells as well as that between the gold particle and the podocyte (Fig. 2) were recorded using the modular system for image analysis. The location of an average of 800 particles was evaluated for each sample.

The specificity of the immunolabelling was assessed by the previously reported control procedures [25]: absorption of the antibody by its specific antigen; use of protein A-gold alone or of non-labelled protein A prior to the protein A-gold.

\section{Results}

Injection of streptozotocin to rats induces the development of an experimental chronic hyperglycaemic state. Indeed, $24 \mathrm{~h}$ after the streptozotocin injection the animals exhibited a significant glycosuria which remained throughout the experiment. Blood glucose levels as determined at time of sacrifice were $25 \pm 4 \mathrm{mmol} / 1$ for the streptozotocin-injected animals versus $7.8 \pm 0.4 \mathrm{mmol} / 1$ for control animals. Plasma insulin levels were $35.2 \pm$ $5.7 \mathrm{mU} / 1$ for the hyperglycaemic animals versus $44.2 \pm$ $2.2 \mathrm{mU} / 1$ for controls; these plasma insulin levels of the hyperglycaemic animals are particularly low when considered in relation to their glycaemia. In addition, immunofluorescence performed on pancreatic tissues showed a major decrease in the number of insulin containing cells in the islets of Langerhans of the hyperglycaemic animals compared with the controls (results not illustrated). These results are in full agreement with those reported previously [36].

The glomerular basal lamina of control normoglycaemic animals appeared as a thin fibrillar layer lying between the endothelial cells of the glomerular capillaries and the podocytes of the epithelial cells (Fig.1a). On the other hand, the basal laminae of the streptozotocin-diabetic animals diplayed a major increase in its thickness (Fig. 1b). The distance between the podocytes and the endothelial cells filled by basal laminae material enhanced significantly. The basal laminae thickness as determined by the orthogonal intercept method was found to be $378.28 \pm 44.96 \mathrm{~nm}$ for hyperglycaemic and $220.61 \pm 9.77 \mathrm{~nm}$ for normoglycaemic animals $(p<$ 0.0005).

When type IV collagen was revealed, using the protein A-gold technique, labelling by gold particles demonstrating type IV antigenic sites was observed over the central lamina densa of the glomerular basal laminae in normoglycaemic animals (Fig. 1 a). Labelling was not found over the capillary lumen, in the urinary space or over the mesangial, epithelial or endothelial cells (Fig. 1a). When the position of the gold particles over the glomerular basal laminae of normoglycaemic animals was analyzed, it was found to be approximately at equal distance between the endothelium and the podocytes. Indeed, the average distance between the gold particles and the endothelium was $115.50 \pm 9.30 \mathrm{~nm}$ while that between the gold particles and the podocytes was $117.10 \pm 8.97 \mathrm{~nm}$. The labelling obtained for type IV collagen over the thickened glomerular basal laminae of the diabetic animals was preferentially located on the subendothelial side of the laminae (Figs. $1 \mathrm{~b}$ and 2). This distribution differs markedly from that obtained on glomerular tissues from control normoglycaemic animals (Fig. 1a) and was consistently found in all the hyperglycaemic animals studied. This preferential labelling of type IV collagen on the subendothelial region of the thickened glomerular basal laminae was confirmed by the morphometrical analysis which showed the distance between the gold particles and the endothelium to be $115.07 \pm 14.17 \mathrm{~nm}$, while that between the gold particles and the podocytes was $264.78 \pm 41.25 \mathrm{~nm}$. It further appeared that the distance between the gold particles and the endothelium remained unchanged in hyperglycaemic and normoglycaemic animals $(115.07 \pm 14.17 \mathrm{~nm}$ versus $115.50 \pm$ $9.30 \mathrm{~nm}$ ) while that between the gold particles and the 

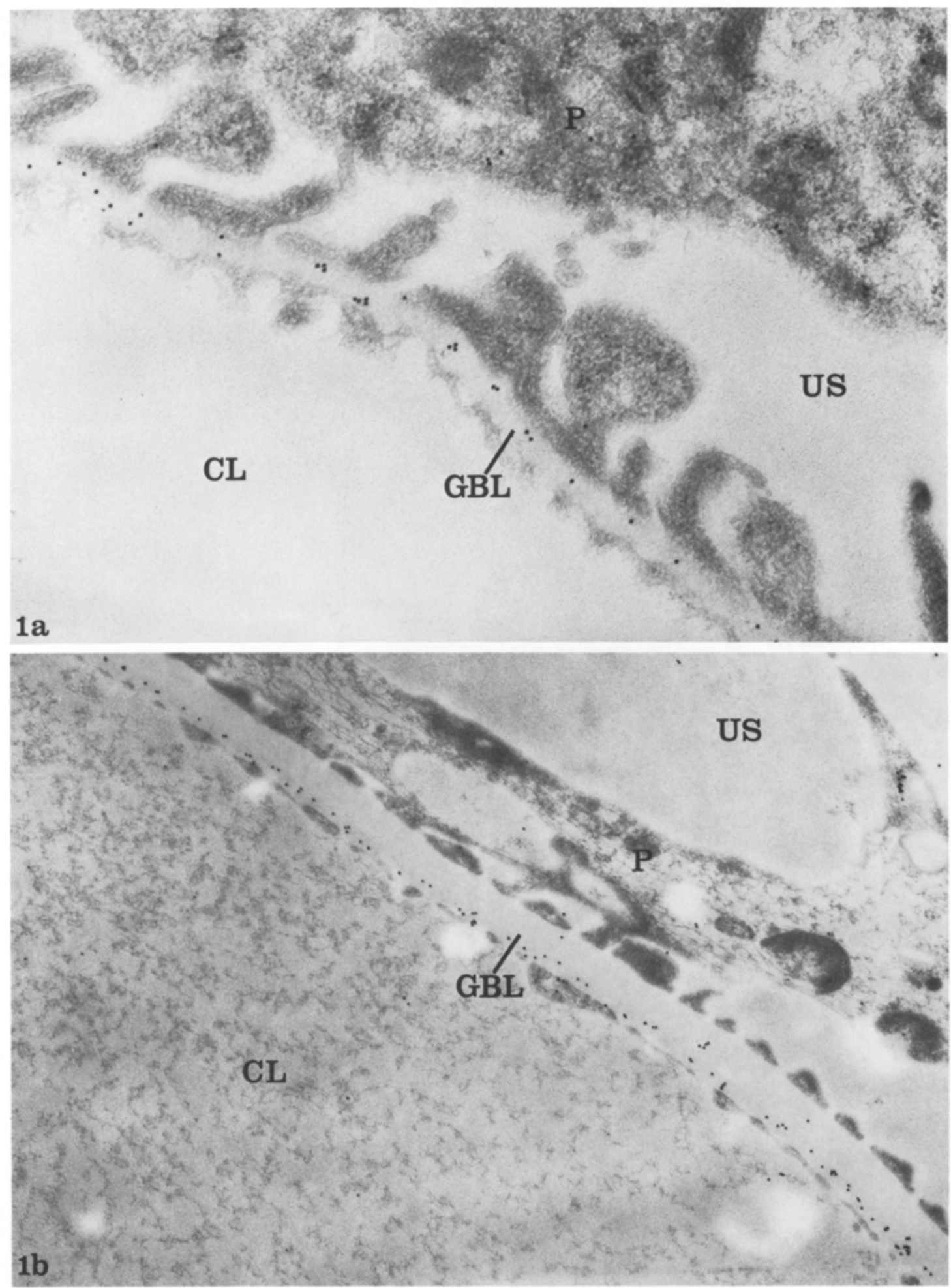

Fig. $1 \mathrm{a}$ and $\mathbf{b}$. Renal tissue from a control normoglycaemic rat (glycaemia: $5.4 \mathrm{mmol} / 1$; insulin: $60.0 \mathrm{mU} / \mathrm{l}$ ), and $\mathbf{b}$ a streptozotocin-induced hyperglycaemic rat (15 months of hyperglycaemic; glycaemia: $20.6 \mathrm{mmol} / \mathrm{l}$; insulin: $27.1 \mathrm{mU} / 1)$. a The type IV collagen antigenic sites labelled by gold particles are preferentially located over the central lamina densa of the glomerular basal laminae (GBL). b The glomerular basal laminae of the hyperglycaemic animal is markedly thickened compared to that of the control. The labelling by gold particles is restricted to the subendothelial side of the laminae, adjacent to the endothelial cells. Few gold particles are present over the podocytes (P), the urinary space (US) and the capillary lumen (CL). a $\times 38000 ; \mathbf{b} \times 28000$ 

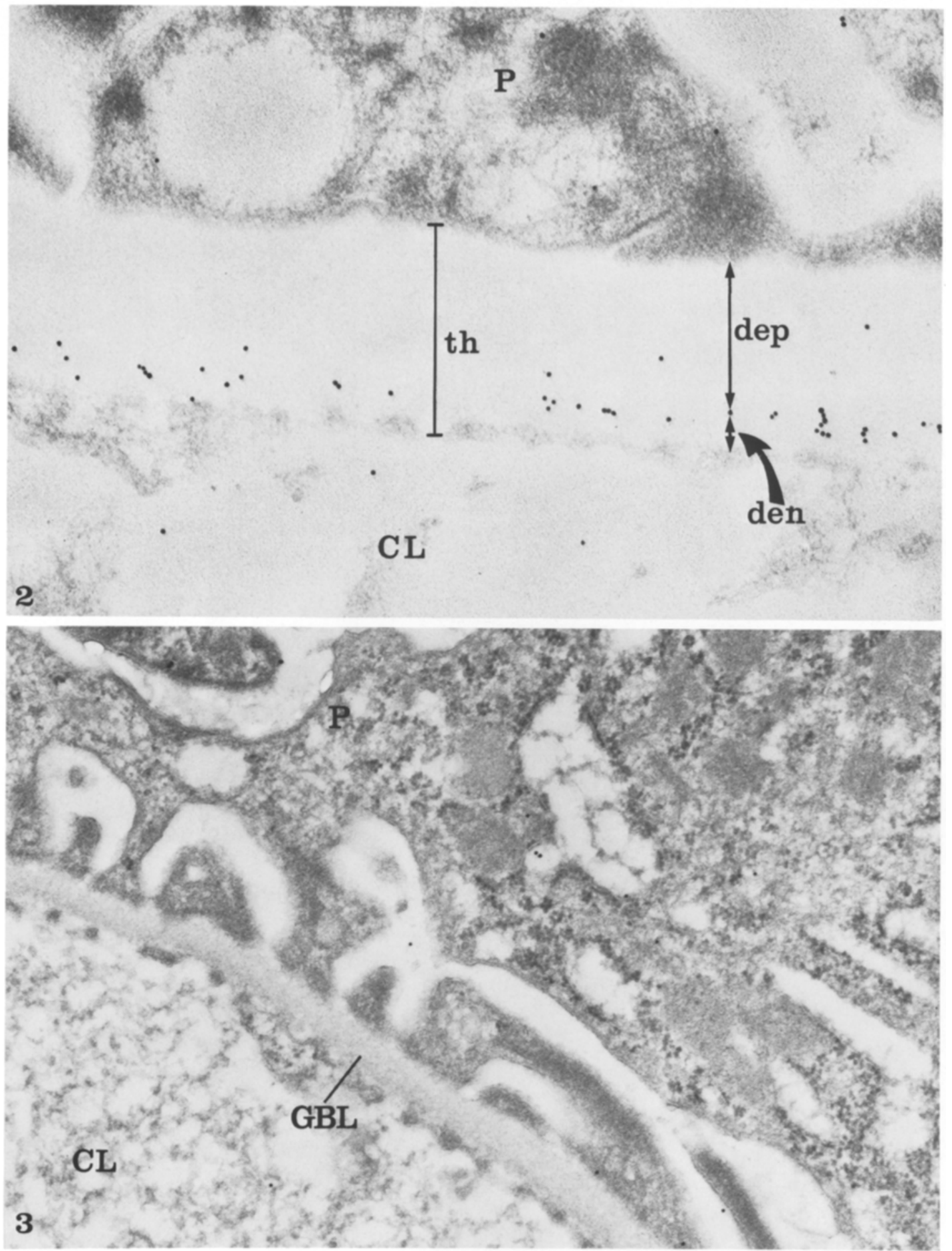

Fig. 2. High magnification of the glomerular basal laminae of a hyperglycaemic animal (10 months of hyperglycaemia; glycaemia: $43.1 \mathrm{mmol} / 1$; insulin: $19.1 \mathrm{mU} / \mathrm{l}$ ). The thickness of the basal laminae is pronounced and the labelling by gold particles appears to be on the subendothelial side. th, thickness of the basal laminae; dep, distance between a gold particle and the epithelial cell ( $P$, podocyte); den, distance between the same gold particle and the endothelial cell; CL, capillary lumen $(\times 65000)$

Fig.3. Renal tissue from a normoglycaemic animal. The tissue section was incubated with anti type IV collagen antibody preabsorbed with its specific antigen followed by the protein A-gold complex, in order to assess the specificity of the labelling. Very few gold particles are present over the glomerular basal laminae $(\mathrm{GBL})$, the capillary lumen $(\mathrm{CL})$ or the podocyte $(\mathrm{P})(\times 38000)$ 
podocytes increased significantly $(264.78 \pm 41.25 \mathrm{~nm}$ versus $117.10 \pm 8.97 \mathrm{~nm}$ ).

When the specificity of the type IV collagen immunolabelling obtained over glomerular basal laminae from normo- and hyperglycaemic animals was assessed, the labelling was markedly reduced using (1) antigenabsorbed-antibodies (Fig.3), (2) protein A-gold complex applied without a previous incubation with the specific antibody or (3) nonlabelled protein A before applying the protein A-gold complex.

\section{Discussion}

Type IV collagen antigenic sites were revealed using the protein A-gold immunocytochemical technique over the glomerular basal laminae of normal and hyperglycaemic rats. The specificity of the labelling obtained was established through the different control experiments performed in this and previous studies [31]. The labelling obtained over the basal laminae of normal animals was found to be restricted to the central laminae densa of the basal laminae and this was supported by morphometrical evaluation. These observations confirm previous results obtained by applying the immunoperoxidase and immunoferritin techniques [16-19]. However, compared with these previous studies in which diffusion is a problem [37], the localization obtained applying the protein A-gold technique appears to be of higher specificity and resolution. Indeed, no labelling for type IV collagen was associated with the plasma membrane of neighbouring cells, reinforcing the fact that type IV collagen is a specific component of the basal laminae.

Concerning the study on hyperglycaemic rats, it has long been established that basal laminae thicken in long term diabetes, leading to, being part of, or resulting from major capillary functional alterations. The glomerular basal laminae of the streptozotocin diabetic animals investigated in the present study were markedly thickened and our subjective and morphometric results are in total agreement with those reported previously [3, 5]. The labelling obtained for type IV collagen over the thickened glomerular basal laminae of the diabetic animals was preferentially located on the subendothelial side of the laminae and this was further confirmed by the morphometrical evaluation. This distribution differs markedly from that obtained on glomerular tissues from control normoglycaemic animals. Thus, it appears that the glomerular basal laminae deposits occuring in the hyperglycaemic state may be antigenically different from that of type IV collagen, or some of the antigenic sites are masked and/or the distribution and proportion of this component are altered. Recent studies have shown that laminin is present in increased amounts in tissues from diabetic animals while proteoglycans are reduced [22-24]. This reduction in proteoglycans which results from either a decrease in the rate of synthesis or in the increase in their degradation, is associated with a significant elevation of the hexose components linked to the collagen portions of the laminae and with a redistribution of the other macromolecules [23]. These alterations take on significance when considered in the light of results showing that proteoglycans as well as the particular arrangement of the different components are implicated in the filtration properties of the glomerular basal laminae [20]. Their decrease and redistribution may then contribute to the loss of the glomerular filtration selectivity reported in diabetes.

Our results thus demonstrate that, in addition to, or concomitant with, the morphological, biochemical and functional alterations already established for the glomerulus in diabetic microangiopathy, modifications in the type IV collagen component also occur in the hyperglycaemic state.

Acknowledgements: The author acknowledges Dr. E. Rasio for his help in the evaluation of the blood samples, Drs G. Martin and H. Stephens for providing the antibodies, Drs R. Østerby and H.J.Gundersen for advice in the measurement of the basal laminae and Ms. D. Gingras and Ms.C. Venne for their excellent technical assistance. This study was supported by grants from the Medical Research Council of Canada and the Canadian Diabetes Association. The author is recepient of a senior scholarship of the Fonds de la Recherche en Santé du Québec.

\section{References}

1. Ditzel J, Rooth G (1955) The micro-angiopathy in diabetes mellitus: A concept regarding the mechanism of its origin. Diabetes 4: 474-476

2. Farquhar MG, Hopper JJR, Moon HD (1959) Diabetic glomerulosclerosis: Electron and light microscopic studies. Am J Pathol 35: 721-753

3. Hirose K, Østerby R, Nozawa M, Gundersen HJG (1982) Development of glomerular lesions in experimental long-term diabetes in the rat. Kidney Int 21:689-695

4. Kilo C, Vogler N, Williamson JR (1972) Muscle capillary basement membrane changes related to aging and to diabetes mellitus. Diabetes 21: 881-905

5. Østerby Hansen R, Lundback K (1970) The basement membrane morphology in diabetes mellitus. In: Ellenbert M, Rifkin $\mathrm{H}$ (eds). Diabetes mellitus: theory and practice. McGraw-Hill, New York, pp 178-209

6. Williamson JR, Kilo C (1976) Basement-membrane thickening and diabetic microangiopathy. Diabetes 25 (Suppl 2): 925-927

7. Beisswenger PJ, Spiro RG (1970) Human glomerular basement membrane: Chemical alteration in diabetes mellitus. Science 168: 596-598

8. Bendayan M, Rasio E (1981) Hyperglycemia and microangiopathy in the eel. Diabetes 30: 317-325

9. Ditzel J, Schwartz M (1967) Abnormally increased glomerular filtration rate in short-term insulin-treated diabetic subjects. Diabetes $16: 264-267$

10. Mogensen CE, Østerby R, Gundersen HJG (1979) Early functional and morphology vascular renal consequences of the diabetic state. Diabetologia 17:71-76

11. Mogensen CE (1971) Glomerular filtration rate and renal plasma flow in short-term and long-term juvenile diabetes. Scand $\mathrm{J}$ Clin Lab Invest 28: 91-100

12. Parving HH (1976) Increased microvascular permeability to plasma proteins in short and long-term juvenile diabetes. Diabetes 25 (Suppl 2): 884-889 
13. Grimaldi A (1982) Physiopathologie de la microangiopathie diabétique. Ann Med Int 133: 114-127

14. Sage H (1982) Collagens of basement membranes. J Invest Dermatol $79: 51 \mathrm{~s}-59 \mathrm{~s}$

15. Stanley JR, Woodley DT, Katz SI, Martin GR (1982) Structure and function of basement membrane. J Invest Dermatol 79: $69 \mathrm{~s}-72 \mathrm{~s}$

16. Courtoy PJ, Timpl R, Farquhar MG (1982) Comparative distribution of laminin, type IV collagen and fibronectin in the rat glomerulus. J Histochem Cytochem 30: 874-886

17. Furthmayr H, Roll FJ, Madri JA, Foellmer H (1982) Composition of basement membranes as viewed with the electron microscope. In: Kuehn K, Shoene H, Timpl R (eds) New trends in basement membrane research. Raven Press, New York, pp 31-48

18. Laurie GW, Leblond CP, Martin GR (1982) Localization of type IV collagen, laminin, heparan sulfate proteoglycan and fibronectin to the basal lamina of basement membranes. J Cell Biol 95: $340-344$

19. Martinez-Hernandez A, Gay S, Miller EJ (1982) Ultrastructural localization of type IV collagen in rat kidney. J Cell Biol 92: 343-349

20. Farquhar MG, Courtoy PJ, Lemkin MC, Kanwar YS (1982) Current knowledge of the functional architecture of the glomerular basement membrane. In: Kuehn K, Schoene H, Timpl R (eds) New trends in basement membrane research. Raven Press, New York, pp 9-29

21. Kanwar YS, Farquhar MG (1979) Isolation of glycosaminoglycans (heparan-sulfate) from glomerular basement membranes. Proc Natl Acad Sci USA 76: 4493-4497

22. Kanwar YS, Rosenzweig LJ, Linker A, Jakubowski ML (1983) Decrease de novo synthesis of glomerular proteoglycans in diabetes: Biochemical and autoradiographic evidence. Proc Natl Acad Sci USA $80: 2272-2275$

23. Parthasarathy N, Spiro RG (1982) Effect of diabetes on the glycosaminoglycan component of the human glomerular basement membrane. Diabetes 31: 738-741

24. Rohrbach DH, Hassell JR, Kleinman HK, Martin GR (1982) Alterations in the basement membrane (heparan-sulfate) proteoglycan in diabetic mice. Diabetes 31: 185-188
25. Bendayan M (1984) Protein A-gold immunocytochemistry: Technical approach, applications and limitations. J Elect Microsc Tech 1: 243-270

26. Roth J, Bendayan M, Orci L (1978) Ultrastructural localization of intracellular antigens by the use of protein A-gold complex. J Histochem Cytochem 26: 1074-1081

27. Rerup CC (1970) Drugs producing diabetes through damage of the insulin secreting cells. Pharmacol Rev 22: 485-518

28. Yalow RS, Berson SA (1960) Immunoassay of endogenous plasma insulin in man. J Clin Invest 39: 1157-1175

29. Jorgensen KR (1969) Evaluation of the double antibody radioimmunoassay of insulin and the determination of insulin in plasma and urine in normal subjects. Acta Endocrinol 60:327-351

30. Coons AH, Leduc EH, Connolly JM (1955) Studies on antibody production. I. A method for the histochemical demonstration of specific antibody and its application to a study of the hyperimmune rabbit. J Exp Med 102: 49-60

31. Stephens H, Bendayan M, Silver M (1982) Immunocytochemical localization of collagen types and laminin in skeletal muscle with the protein A-gold technique. Biol Cell 44: 81-84

32. Gundersen HJG, Jensen TB, Østerby R (1978) Distribution of membrane thickness determined by lineal analysis. J Microscopy 113: $27-43$

33. Kleinman HK, McGarvey ML, Liotta LA, Robey PG, Tryggrason K, Martin GR (1982) Isolation and chracterization of type IV procollagen, laminin and heparan-sulfate proteoglycan from the EHS-sarcoma. Biochem 24: 6188-6193

34. Timpl R, Martin GR, Bruckner P, Wick G, Wiedmann H (1982) Nature of the collagenous protein in a tumor basement membrane. Eur J Biochem 84: 43-52

35. Rennard SI, Berg R, Martin GR, Foidart JM, Gehron Robey P (1980) Enzyme linked immunoassay for connective tissue components. Anal Biochem 104: 205-214

36. Orci L (1976) A fresh look at the interrelationships within the islets of Langerhans. In: Schanttauer FK (ed) Diabetes research today. F. K. Schattauer, Stuttgart, pp 135-151

37. Courtoy PJ, Picton DH, Farquhar MG (1983) Resolution and limitations of the immunoperoxidase procedure in the localization of extracellular matrix antigens. J Histochem Cytochem 31: 945-951 